IRA-International Journal of Applied Sciences ISSN 2455-4499; Vol.04, Issue 01 (2016)

Institute of Research Advances http://research-advances.org/index.php/IRAJAS

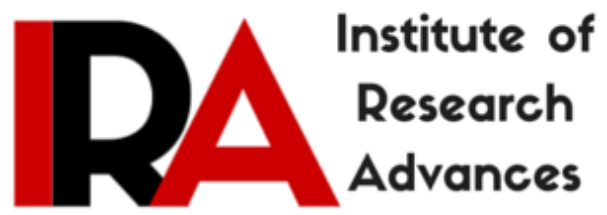

\title{
Seasonal Variations in Sedimentological Characteristics of Uppanar River Estuary, South East Coast of India
}

\author{
${ }^{1}$ S. Jasmine Sheeba, ${ }^{2}$ G. Ramesh, ${ }^{3}$ G. Gnanachandrasamy, ${ }^{4}$ T. Ramkumar, \\ ${ }^{5}$ Magdalina Monica Rozaria, ${ }^{6}$ K. Sujatha \\ 1,2,3,4,5,6 Department of Earth Sciences, Annamalai University, \\ Annamalai Nagar, 608002.India.
}

DOI: http://dx.doi.org/10.21013/jas.v4.n1.p5

\section{How to cite this paper:}

Sheeba, S., Ramesh, G., Gnanachandrasamy, G., Ramkumar, T., Rozaria, M., \& Sujatha, K. (2016). Seasonal Variations in Sedimentological Characteristics of Uppanar River Estuary, South East Coast of India. IRA-International Journal of Applied Sciences (ISSN 2455-4499), 4(1). doi:http://dx.doi.org/10.21013/jas.v4.n1.p5

(C) Institute of Research Advances

(cc) EY-NC

This works is licensed under a Creative Commons Attribution-Non Commercial 4.0 International License subject to proper citation to the publication source of the work.

Disclaimer: The scholarly papers as reviewed and published by the Institute of Research Advances (IRA) are the views and opinions of their respective authors and are not the views or opinions of the IRA. The IRA disclaims of any harm or loss caused due to the published content to any party. 


\begin{abstract}
The estuaine environment are dynamic and they are the intermediate zone between the marine and fresh water regions. This makes the estuarine region more dynamic in physical and chemical characteristic. These regions serves as a passage for the continental materials reach the marine environment. Because of the influence of fresh water and marine water this regions the depositional systems are dynamic and complex in nature. Despite the complexity of the of the environment, the textural analsysis and interpretation of the same provides insight into the prevailing deposition environment. The present study are carried out in the Uppar Estuary which joins with Bay of Bengal on the east coast of India. The Sedimentological analysis indicates that sediments most of the locations the sediments are very poorly to well sorted with mean size ranging from 1.03 to $5.97 \varphi$. The skewness value ranged from -0.09 to 0.48. The kurtosis varies form 0.94 to 1.54 The seasonal variations within the station are conspicuous. This indicates the sediment distribution pattern in controlled by the marine as well monsoon rainfall in this region.
\end{abstract}

Keywords: Sedimentology, Grain size statistics, Estuarine sediments

\title{
INTRODUCTION
}

Estuaries are regions of fundamental importance with respect to weathering processes occurring on the global scale, as they represent the major rout whereby weathered lithospheric material is transported to the oceanic sedimentary domain (Morris, 1978). Estuaries are thus, the most complex of all aquatic environments with regard to the source and composition of aquatic sediments (Leenheer, 1991).

Sediments are moved into an estuary both as suspended load and bed load. The nature of sediment bed formation depends on the energy transmission to the particles, which in turn controlled by the transport modes. In many estuaries, tides are the major energy source for mixing fresh and salt water, for resuspending sediments from the bed and also for transporting suspended sediments either to seaward or landwards.

Depositional processes in estuaries include particulate flocculation and deposition with increasing salinity (Krone, 1962) and organic particulate interactions, however, are difficult to identify or quantify because of the complex hydrology that affects depositional processes in estuaries as reported by Meade (1972). On mixing of fresh water with estuary, the increase in salinity and sometime $\mathrm{pH}$ would lead to flocculation of iron oxides, humic substances, and other colloidal particles such as clays, which are then deposited together with their absorbed or coprecipitated trace metals (Bryan, 1984). Chnges in the dynamic properties of river water in the estuarine environment result in the accumulation of fine-grained sediment with a high organic- matter content, which can, through adsorption processes, play an important role in the transport of trace elements to the sea floor (water-sediment interface) (Krauskopf, 1956; Burton and Liss, 1976). Thus, the organic substances in estuarine environment can be regarded as a mixture of terrestrial and marine end members (Mayer, 1985).

Although, estuaries are often considered as protected environments, the waves generated externally in the ocean that penetrate estuary mouth or by the waves generated internally could affect shores, marginal shores and also the estuarine floor. The net effect could be significant on the pattern of sedimentalogy, the eroding nature of the shores, in stripping substrates and suspend the sediment the sediments which could be subsequently be dispersed by the currents. A further effect of ocean waves is to erode sand from the beach or shore face and to transport it via longshore or drift currents towards the estuarine entrance. Thus, the effect of waves are both depositional and erosional in nature. Shore erosion and local redistribution are self-digesting processes (Rusmate 1967) that enlarge the estuary but decreased its total volume. Thses dynamic physical processes could thus produce distinctive sedimentary pattern and also retain the sediment load in an estuary. 
Despite the complexity of bio-geochemical processes in the estuarine environment, textural pattern of sediments which mostly approaches dynamic equilibrium with waves and tidal activities are good indicators of energy variations (Allen 1971). It has been well recognized that the grain size distributions reflect the hydraulic environment in which the grains were transported and deposited. Several approaches have been used to interpret depositional environments from grain size distributions such as plotting skewness versus sorting (Friedman 1961) and comparing the coasrsest fraction to the median size (Passegial 1964, Middleton 1976). Sagoe and Visher (1977) have also examined the relationships between grain size distribution and hydraulics and they emphasized that the effects of the transporting fluid on sediment grains provide a basis for interpreting hydraulic conditions from grain size distributions.

Analysis of textural parameters to delineate transport mechanisms and depositional environments is widely employed in studying modern sedimentary provinces. Significant advances have been made in the comprehension of the interactions existing between sediment transport and environmental energy. Attempts made by many have been found successful in delineating distinct depositional environments using different combinations of textural parameters. Studies by Folk and Ward (1957), Masson and Folk (1958), Friedman (1961; 1967), Visher (1969), Allen (1971) demonstrated that distinct environments leave a definite imprint on the grain size and sorting indices of sand populations.

\section{DISCRIPTION OF THE STUDY AREA}

The Uppanar estuary is formed by the confluence of Gadilam and Paravanar rivers. The river Gadilam originates from the foothills of northestern part of the Shevarayan hills and later flows Virdhaclakam Taluk of Cuddalore district. Uppanar estuary is also an open type estuary and the width of the mouth is around $30 \mathrm{~m}$. Mean tidal amplitude is around $90 \mathrm{~cm}$, extending the tidal effect upto $5 \mathrm{~km}$ upward, and the pattern is semidiurnal. The cuddalore fishing harbour is situated near the mouth of the Uppanar estuary, which is one among the important fishing harbours of Tamil Nadu. SIPCOT (State Industries Promotion Council of Tamil Nadu) is located on the northern bank of Uppanar estuary covering an area of about 520 acres with 44 industries, which include chemicals, petrochemicals, pharmaceutics, pesticides, fertilizers and metal processing industries. Most of the industries are wet process industries and consume large quantity of water in the manufacturing process, releasing large volume of effluents in to the Uppanar estuary. Uppanar is a relatively smaller river which carries mainly municipal and domestic wastes and organic wastes from coconut husk retting sities, the waste water from nearby agricultural lands is discharged into this estuarine complex. The waste water from nearby agricultural land is discharged into this estuarine complex. The estuary is relatively polluted, receiving chemicals as well as organic pollutants. The study area in the Uppanar consists four stations as shown in figure. The station one is close to the sea and the station fine is in the upstream of the estuary region. Four seasons are recognized based on the northeastern monsoon, as summer (April to June), Premonsoon (July to September), monsoon (October to December) and Postmonsoon (January to march). There will also be some occasional showering under the influence of southwest monsoon without changing very much the environmental and biological parameters. 
IRA-International Journal of Applied Sciences

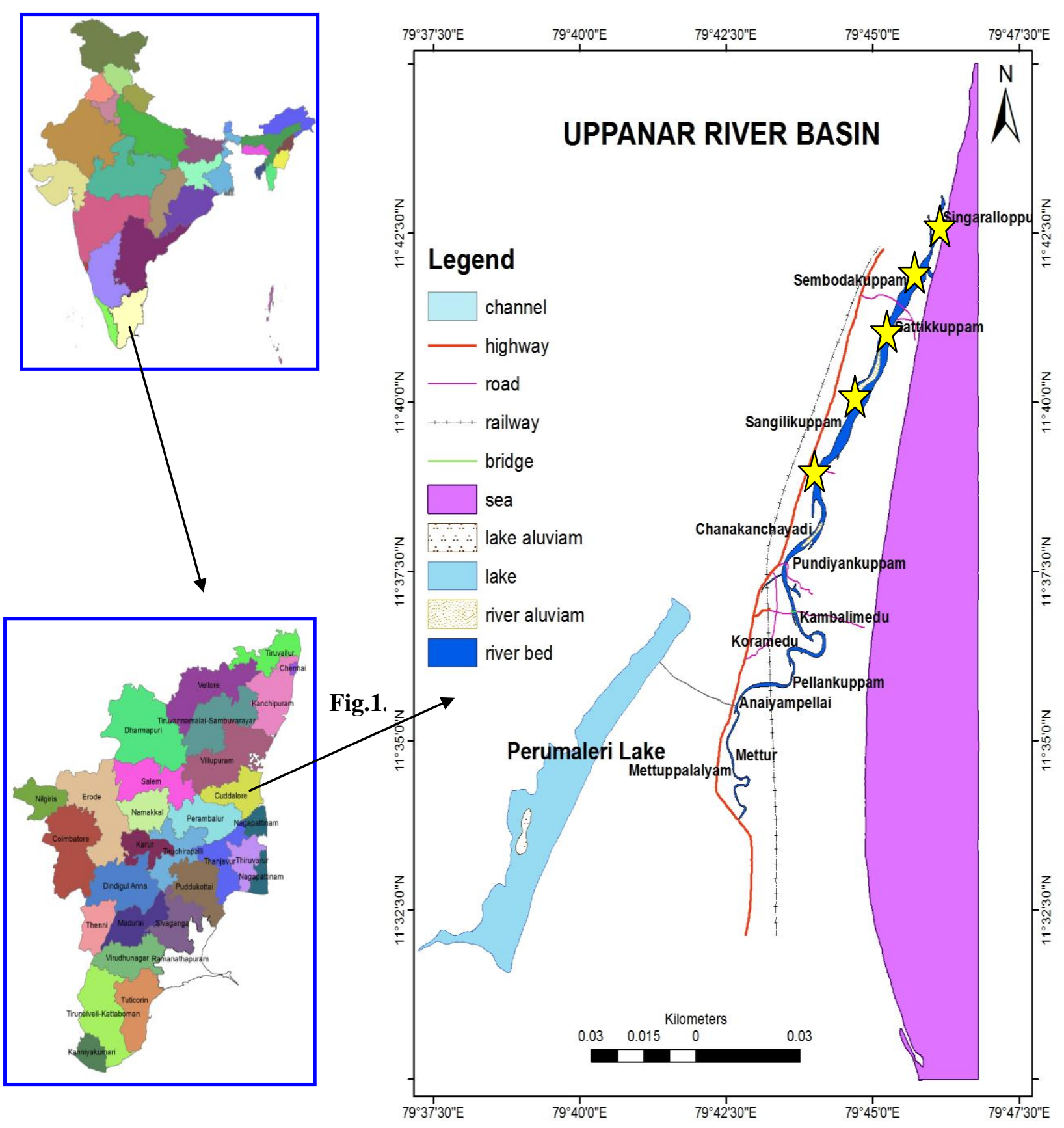




\section{MATERIALS AND METHODS}

Sediment samples were collected from six different locations of the Uppanar estuary (fig.1) for a period of two years from January 2009 to December 2011. The seasonal sampling were made as with reference to North East Monsoon as, Post Monsoon (January to March), Summer (April to June), Premonsoon (July to September), and Monsoon(October to December). Sediment samples were collected from five locations by using grab sampler and surface $2 \mathrm{~cm}$ of the samples was taken scooped with plastic spatula and stored in the laboratory for further analysis. Textural analysis of the sediments was carried out by the Laser Beam particle size analyser (Horiba LA200) after taking known quantity of sample (the sediment samples are freed from shell debris before preserving) by coning and quartering method. The grain size analysis results obtained for the samples were used for the calculation of statistical parameters Statistical parameters such as mean size (Mz), Inclusive Graphic Sandard Deviation ( $\sigma$ ), Inclusive Graphic Skewness,(Ski) Graphic kurtosis (KG) were calculated by following the procedure of Folk and Ward (1957) formula and the resulting values are expressed in phi units.

\section{RESULTS AND DISCUSSION}

The average size of sediments phi mean size $(\mathrm{Mz})$ is represented in the cumulative graph. The variation in phi mean size between stations and seasons are distinguishable. It can be observed that stations 1 and 2 from a set and 3 and 4 from another set as also the stations 5 form third set with respect to range and variations noted in the mean size. The mean size ranged from 1.94 to $2.4 \varphi, 2.33$ to $5.59 \varphi, 5.37$ to $5.95 \varphi, 4.47$ to $5.79 \varphi$ and 1.03 to $1.94 \varphi$ at stations $1,2,3,4$, and 5 respectively. The mid estuarine region recorded the higher phi mean size compared to the stations (Table 2).

Standard deviation values reflect the energy of depositional environment. The results of the inclusive standard deviation and sorting character of all the samples were shown in Table 5. The standard deviation values are slightly higher at stations 3 and 4 when compared to other stations. However, the seasonal variations are uniform in nature irrespective of stations. The values ranged from 0.67 to $0.98 \varphi, 0.64$ to $1.25 \varphi, 1.21$ to $2.76 \varphi, 1.19$ to $2.2 \varphi 4$ and 0.37 to $1.69 \varphi$ for stations $1,2,3,4$ and 5 respectively. These are nature of sorting classes, which ranged from very poorly sorted to well sorted in the present investigation

In the present study skewness values ranged between- 0.09 to $0.23 \varphi, 0.09$ to $0.3 \varphi 6,0.34$ to $0.48 \varphi, 0.24$ to $0.44 \varphi$ and 0.16 to $0.29 \varphi$ at stations $1,2,3,4$ and 5 respectively. In general, skewness ranged from very fine skewed (positive) to very coarse skewed (negative). The entire skewness values and their classification are shown in table 6 for all the stations.

The kurtosis values for all the five stations were shown in table 1 . The values ranged from very platykurtic to very leptokurtic. In general the kurtosis values ranged from 1.13 to $1.37 \varphi$ at station $1 ; 0.99$ to $1.47 \varphi$ at station $2 ; 1.15$ to $1.54 \varphi$ at station $3 ; 0.99$ to $1.35 \varphi$ at station 4 ; and 0.94 to $1.38 \varphi$ at station 5 during the course of the present study.

The changes with respect to seasons and stations are well noticeable (Table 2). In general, the mean size was highest at mid estuarine regions (station 3 and 4) and thereafter it decrease both in upstream and downstream directions. All these indicate that there existed a decrease in grain size in the direction of transport in a river channel. This could mainly be due to the differential transport mechanism as stated by Folk and Ward (1957), Scheideger (1961) and Allen (1965 as well as by abrasion Theil (1940). In nature, these two processes operate together and ultimately resulting in the grain size reduction. The standard deviation value refers to sorting of the sediments which was decreased on both sides from the mid of the estuary as that of phi mean size. This indicates the influence of the mean grain size of the sorting nature of the sediments. Except during monsoon season, the sediments are poorly to very poorly sorted. The decrease in standard deviation values during monsoon indicate the removal of finer materials leading to a better sorting of sediments. According to Inman (1949), once the sediments attain the maximum sorting value, any further fall in the competency of water flow result in the increase of fine particles and result in the poor sorting. Similar observation were recorded by Rao et al. (1988) in Krishna delta, Swamy et al. (1983) in Vishakapatnam-Bhoomipattinam beach sands, Malik et. al. (1993) in Mandapam Palk bay shelf 
sediments, Sasidharan (1988) in beach sands of northern part of kerala coast. In the present investigation the sediments of the study area are found to be polymodal nature and the primary mode was observed to vary between the stations and within stations and also with the change in the seasons. This was similar to the observations made by Malik (1983) on the shelf sediments of Palk bay. Folk and ward (1957) also pointed out that small change in primary mode with in the sand mode would affect the sorting values.

Skewness, a measure of the degree of symmetry, describes the tendency of the data to spread preferentially of one side of the average. It is an important parameter in grain size studies since it is a sensitive indicator of sub population mixing.

The skewness values (table 6) reveal that most of the sediments during 2009 are either fine skewed or very fine skewed. But there was a change in this pattern during 2010. This indicates the presence of considerable amount of finer particles in the system make the right hand side of the curve more distinct which influences the skewness value. This is similar to the observation of Sathyanarayana et al. (1993) in the coastal sediments of Visakhapatnam. These phenomenon have also been reported by Folk and Ward (1957) which has been further explained by Friedman (1961) and martin (1965). The existence of negatively skewed sediments at stations 1 and 2 indicates that these stations are comparatively high energy zone where fine sediments are removed by winnowing action of waves and coarse sediments are slowly concentrated together with little addition of coarse may, probably, be the reason. . Kurtosis measures the ratio of the sorting in the extreme of the grain size spectrum compared with sorting in the central portion. All stations exhibit a wide range of value from platykurtic to leptokurtic nature. Majority of the sediments are leptokurtic nature during the two years of study. However during 2010 there is a increase in the mesokurtic group which in turn leads to a decrease of 8.29 percent in the leptokurtic nature during the same year. Stations 1, 2 and 5 encompasses majority of the mesokurtic and leptokurtic nature whereas the stations 2 and 3 exhibit a less occurrences of individual group bur exhibits a wide range of kurtosis values. Folk and Ward (1957) and Cadigan (1961) classified kurtosis as leptokurtic if the central part of the grain size distribution is relatively better sorted that of the average in tails, whereas the converse is true in the case of platikurtic. The highest and lowest kurtosis values were found to be associated with very poorly sorted sediments. This is parallel to the observation of Folk and Ward (1957).

\section{CONCLUSION}

The seasonal variations in the mean water discharge, and the flow velocity related to the mean discharge together would have thus influenced the differential transport mechanism of sediments. Hence the change in the mean discharge of water may be accounted for the above said differences. Relatively low phi mean size observed in the mouth region and this could mainly be due the constant waves and tidal actions which carries and prevents the settling of fines leaving the coarser material resulting in the decrease of phi mean size. The degree of improvement of sorting was noticed in the moderate class rather than very well sorted nature. Thus such sorting class variations within the study area were due to the influence of hydrodynamic environmental conditions.

The wide range of occurrence of sorting (from well sorted to very poorly sorted) nature indicates the existence of the hydraulic energy and its influence over the sorting character of the sediments. The polymodal nature of the sediments and variations in the mode of populations coupled with the hydraulic conditions would have thus influenced the skewness value in the study area. The comparison with the skewness versus kurtosis, the symmetrically skewed sediments exhibit platykurtic to leptokurtic nature with majority in the mesokurtic class. Likewise the well sorted sediments exhibit mesokurtic to leptokurtic nature. Occurrence of wide range of kurtosis values in the study area indicate the mixing of two or more populations, this is especially prominent in the case of stations 3 and 4 where the station exhibit such a wide range of kurtosis value supports the above mentioned polymodal nature. The present investigation reveals that the sediment distribution nature in the study area varied with respect to seasonal changes and more variation were observed in the latter period of the study (2010). The nature variations observed between the stations, behave distinctly and the distribution of sediments at stations 1 and 2, behave more or less similar to stations 3 and 4 
whereas stations 5 from a different set in terms of both nature and distribution of sediments. Thus, altogether 3 sets could be observed as stations 1 and 2, stations 3 abd 4 and stations 5 . This type of distribution of sediments in the estuary, as distinct areas, suggests the existence of the prevailing hydrodynamic condition of the study area as the major influencing parameter coupled with monsoon rainfall in this region.

\section{REFERENCES}

Allen, J.R.L. (1965). A review of the origin and characteristics of recent alluvial sediments. Sedimentalogy, 5: 89-191.

Allen, G.P. (1971). Relationship between grain size parameter distribution and current patterns

Bryan, G.W., (1984). Pollution due to heavy metals and their compounds, Mar. Eco., 5(3): 12891430 .

Cardigan, R.A. (1961) Geologic interpretation of grain size distribution measurements of Colorado plateau sedimentary rocks. J. Geol., 69: 121-142.

Folk, L.R. and Ward, C.W. (1957). Brazos River Bar: A study in the significance of Grain Size Parameters.

Friedman, G.M., (1961) Distinction between dune, beach and river sands from their textural characteristics. J. Sedi. Petrol., V.31: 514-529.

Friedman, G.M., (1967). Dynamic processes and statiscal parameters compared for size

Inman, D.L. (1949) Sorting of sediments in the light of fluid mechanics: J. Sedim. Petrol., 19: 51-70.

Krauskopf, K. (1956) Factors controlling the concentration of thirteen rare metals in sea water. Geochimica et cosmochimica Acta, 9: 1 - 32.

Krone, R.B., (1962). Flume Studies of the transport of sediment in Estuarial shoaling process - Final Report (Berkeley, CA: Univ. California Hydraulic Eng. Lab. And Sanitary Eng. Research Lab.

Langston, W.J. and Bryan, G.W., (1984). The relation - Ship between metal speciation in the environment and bioaccumulation in aquatic organisms. In: complexation of Trace Metals in Natural Waters, Cramer, C.J.M. and Duinker, J.C., (eds.), Martin Nijhoff / Dr. W. Junk publishers. Pp 375 - 392.

Malik, T.K. (1983). Shelf sediments and mineral distribution patterns off mandapam, Palk Bay. Indian j. Mar. Sci., 12: 203-208.

Mason, C.C. and Folk, R.L. (1958). Differentiation of beach, dune Aeolian flat environments by size analysis. J. Sedim. Petrol., 28: 211-226

Mayer, L.M., (1985). Geochemistry of humic substances in estuarine environments, in: humic substances in soil, sediment, and water: Geochemistry, Isolation, and characterization, G.R. Aiken, D.M. Mcknight, R.L. Wershaw, and P. Maccrthy, (eds), New York: John Wiley and Sons, PP, 211-232.

Malik, T.K. (1983). Shelf sediments and mineral distribution patterns off mandapam, Palk Bay. Indian j. Mar. Sci., 12: 203-208.

Meade, R.H., (1972). Transport and deposition of sediments in estuarines, memoir 133, Geological Society of America, Inc. PP 91-120. 
Middleton, G.V. (1976) Hydraulic interpretation of sand size distributions. J. Geol., 84: PP 405-426.

Morris, A.W. (1978) Environmental biogeochemistry and geobiology. (Ann.Arbor. Science Publications Michigan), P 387.

Rao, B.K., Rao, P.S and Swamy, A.S.R. (1988). Granulometric studies on modern barrier system of the right bank of Krishna delta, East Coast of India. 17: PP 283-286.

Sagoe, K.O. and Visher, G.S. (1977). Population breaks in grain size distributions of sand: A Theoretical Model. J. Sedim. Petrol. 47: PP 285-310.

Sasidharan, K. and Damodaran, K.T. (1988) Texture and mineralogy of beach sands of the northern part of Kerala Coast. Mahasagar, 21(4): 209-217.

Scheidegger, A.E. (1961) Theoretical geomorphology, Englewood cliffs, Prentice Hall Inc. New York, 333.

Swamy, A.S.R., Sastry, A.V.R and Vasudev. K. (1983). Granulaometric studies of visakapatnambhimunipatnam beach sands. Indian j. Mar. Sci., 12: 110-111.

Theil, G.A. (1940). The relative resistance of abrasion of mineral grain of sand size. J. sedi. Petrol., 10: $102-124$.

Visher, G.S. (1969) Grain-size distributions and depositional processes. J. Sedim. Petrol. 39: 10741106. 
(Tables \& Figures)

Table-1. Textural Classification of Sediments

\begin{tabular}{|c|c|c|c|c|c|c|}
\hline $\begin{array}{l}\text { Month \& } \\
\text { Year }\end{array}$ & Station 1 & Station 2 & Station 3 & Station 4 & Station 5 & Station 6 \\
\hline $\begin{array}{l}\text { January } \\
2009\end{array}$ & sand & Sand & Silty-sand & Silty- sand & Silty-sand & Sand \\
\hline February & Sand & Sand & Silty-sand & Silty-sand & Sand & sand \\
\hline March & Silty-sand & Silty-sand & Silty-sand & Silty-sand & Sand & sand \\
\hline April & Silty-sand & Silty-sand & Silty-sand & $\begin{array}{l}\text { Sand-silt- } \\
\text { clay }\end{array}$ & Sand & Sand \\
\hline May & Silty-sand & Silty-sand & Silty-sand & Silty-sand & Sand & Sand \\
\hline June & Silty-sand & Silty-sand & Silty-sand & Silty-sand & Sand & Sand \\
\hline July & Sand & Silty-sand & Silty-sand & $\begin{array}{l}\text { Silt-sand- } \\
\text { clay }\end{array}$ & Sand & Sand \\
\hline August & Sand & Silty-sand & Silty-sand & Silty-sand & Sand & Sand \\
\hline September & Sand & sand & Sand & Silty-sand & Silty-sand & Sand \\
\hline October & Sand & Sand & Sand & Sand & Sand & Sand \\
\hline November & Sand & Sand & Sand & Sand & Sand & Sand \\
\hline December & Sand & Sand & Sand & Sand & Sand & Sand \\
\hline $\begin{array}{l}\text { January } \\
2010\end{array}$ & sand & Sand & Sand & sand & sand & Sand \\
\hline February & Sand & Sand & sand & Sand & sand & Sand \\
\hline March & Sand & Sand & Sand & Sand & Silty-sand & Sand \\
\hline April & Sand & Sand & $\begin{array}{l}\text { Silt-sand- } \\
\text { clay }\end{array}$ & Sand & Silty-sand & Sand \\
\hline May & Sand & Sand & $\begin{array}{l}\text { Silt-sand- } \\
\text { clay }\end{array}$ & Sand & Silty-sand & Sand \\
\hline June & Sand & Sand & $\begin{array}{l}\text { Silt-sand- } \\
\text { clay }\end{array}$ & Sand & Silty-sand & Sand \\
\hline July & Sand & Sand & Silty-sand & Sand & Silty-sand & Sand \\
\hline August & Sand & Sand & Silty-sand & Sand & Silty-sand & Sand \\
\hline September & Sand & Sand & Sand & Sand & Sand & Sand \\
\hline October & Sand & Sand & Sand & Sand & Sand & Sand \\
\hline November & Sand & Sand & Sand & Sand & Sand & Sand \\
\hline December & Sand & Sand & Sand & sand & Sand & sand \\
\hline
\end{tabular}


Table. 2. Grainsize Statistical Parameters of the Sediments of the Uppanar River Estuary ( All Values in Phi Units)

\begin{tabular}{|c|c|c|c|c|c|c|c|c|c|c|}
\hline \multirow{2}{*}{$\begin{array}{l}\text { Mean } \\
\text { Size } \\
\text { Station/ } \\
\text { Seasons }\end{array}$} & \multicolumn{4}{|c|}{2009} & \multicolumn{4}{|c|}{2010} & \multirow{2}{*}{ Min } & \multirow{2}{*}{ Max } \\
\hline & Monsoon & $\begin{array}{l}\text { Post } \\
\text { Monsoon }\end{array}$ & Summer & $\begin{array}{l}\text { Pre } \\
\text { Monsoon }\end{array}$ & Monsoon & $\begin{array}{l}\text { Post } \\
\text { Monsoon }\end{array}$ & Summer & $\begin{array}{l}\text { Pre } \\
\text { Monsoon }\end{array}$ & & \\
\hline 1 & 1.57 & 1.97 & 2.07 & 1.84 & 1.94 & 2.15 & 2.4 & 1.97 & 1.94 & 2.4 \\
\hline 2 & 2.13 & 2.19 & 2.24 & 2.08 & 2.33 & 2.34 & 2.59 & 2.63 & 2.33 & 5.59 \\
\hline 3 & 5.16 & 5.42 & 5.73 & 5.31 & 5.37 & 5.61 & 5.95 & 5.44 & 5.37 & 5.95 \\
\hline 4 & 4.37 & 4.94 & 5.47 & 4.63 & 4.47 & 5.39 & 5.79 & 5.06 & 4.47 & 5.79 \\
\hline 5 & 1.29 & 1.61 & 1.79 & 1.94 & 1.38 & 1.12 & 1.69 & 1.03 & 1.03 & 1.94 \\
\hline \multicolumn{11}{|c|}{$\begin{array}{l}\text { Standard } \\
\text { Deviation }\end{array}$} \\
\hline 1 & 0.67 & 0.81 & 0.98 & 0.97 & 0.74 & 0.89 & 0.98 & 0.91 & 0.67 & 0.98 \\
\hline 2 & 0.64 & 1.22 & 0.91 & 1.25 & 0.79 & 0.97 & 1.08 & 0.98 & 0.64 & 1.25 \\
\hline 3 & 1.43 & 2.26 & 2.41 & 1.21 & 2.14 & 2.36 & 2.76 & 1.36 & 1.21 & 2.76 \\
\hline 4 & 1.24 & 1.19 & 2.08 & 1.27 & 1.97 & 2.24 & 1.69 & 1.24 & 1.19 & 2.24 \\
\hline 5 & 0.57 & 0.71 & 0.94 & 0.97 & 0.37 & 1.69 & 0.64 & 0.98 & 0.37 & 1.69 \\
\hline \multicolumn{11}{|c|}{ Skewness } \\
\hline 1 & -0.07 & -0.02 & 0.14 & -0.02 & -0.09 & 0.23 & 0.14 & -0.08 & -0.09 & 0.23 \\
\hline 2 & 0.13 & 0.36 & 0.09 & 0.24 & 0.21 & 0.31 & 0.28 & 0.23 & 0.09 & 0.36 \\
\hline 3 & 0.42 & 0.38 & 0.45 & 0.34 & 0.39 & 0.43 & 0.48 & 0.43 & 034 & 0.48 \\
\hline 4 & 0.24 & 0.37 & 0.37 & 0.38 & 0.29 & 0.4 & 0.44 & 0.33 & 0.24 & 0.44 \\
\hline 5 & 0.29 & -0.11 & -0.13 & 0.11 & -0.08 & -0.12 & -0.07 & -0.16 & -0.16 & 0.29 \\
\hline \multicolumn{11}{|l|}{ Kurtosis } \\
\hline 1 & 1.013 & 1.33 & 1.13 & 0.98 & 1.13 & 1.37 & 1.17 & 1.19 & 1.13 & 1.37 \\
\hline 2 & 1.36 & 1.07 & 1.14 & 0.97 & 1.47 & 1.27 & 1.24 & 0.99 & 0.99 & 1.47 \\
\hline 3 & 1.11 & 1.17 & 1.34 & 1.04 & 1.54 & 1.39 & 1.15 & 1.15 & 1.15 & 1.54 \\
\hline 4 & 1.04 & 1.24 & 1.35 & 1.24 & 0.99 & 1.27 & 1.11 & 1.2 & 0.99 & 1.35 \\
\hline 5 & 0.67 & 1.09 & 0.94 & 1.11 & 0.94 & 1.19 & 1.38 & 1.24 & 0.94 & 1.38 \\
\hline
\end{tabular}

